Hassan, Amna

DOI: 10.15170/DIKE.2019.03.02.11

PhD student

PTE ÁJK

\title{
Impact of the European Private Law Codification outside Europe I: Common Law in the Old Colonial Empire (Pakistan)
}

The paper provides insight into the existence of codified private law in a Common law colony - Pakistan - outside the realm of Europe. As the Britain ruled the subcontinent for a long period of time, therefore, Pakistan continued to follow the Common law system regulated by their British colonizers. It gives a detailed account of the existence and application of common law in the subcontinent, and on the intent of the British to codify the laws in the region to accomplish their 'divide and rule' policy for the administration of the subcontinent. Using this as the proverbial measuring stick, the paper then seeks to justify a parallel system of codified private laws in existence in Europe, in a compact manner. Not only this, the paper also reflects upon the impact of the codified private law in the legal development of Pakistan as a whole till to date. For that purpose, an explanatory over-view of the Indian Contract Act of 1872 is provided including the history, traditional and common law roots, and the Act, itself.

Keywords: European private law codification, impact on Pakistan, old British colony, subcontinent and common law, impact on legal development, Indian Contract Act 1872

\section{Introduction}

There are mainly five kinds of legal systems that are being followed by almost all the countries around the world, namely the common law system, civil law system, customary law, religious law and pluralistic law. In addition, there is one other kind of legal system existent that is international law, but this kind deals with relationships of one independent country with another at an international scenario. However, out of all the legal systems, it is the civil law system or commonly referred to as the European continental law that is widespread and applied around the world in nearly one-fifty countries in the world. The civil law is basically derived from the ancient Roman body of civil law known as Corpus Juris Civilis. The fundamental core of any civil legal system is the fact that all the laws are written down in the form of codes. The main or primary source of law in any civil system is considered to be the legislation, that is to say the constitution or acts of parliament passed and enforced by the government of a country. Whereas, customs are regarded as secondary sources of law under civil law system. Another popular kind of legal system is the common law system, also known by the English common law based on the fact that the British were considered to be its 
pioneers and follow it till to date along with nearly eighty other countries formerly colonized by the British, including Pakistan. The common law system was inspired from the laws introduced by the Romans, Anglo-Saxons, and Normans. The basis of this system depends upon the stare decisis, also known as the legal precedent, that is considered the primary source of law in any common law system. The judge made law is held supreme in a common law system and customs are valued as authority.

Pakistan is a living example of English common law system in combination with the Islamic Sharia Law, due to the fact that Pakistan was part of the subcontinent colonized by the British. During that time, British introduced common law system in the subcontinent which finds its strongly embedded roots in the subcontinent even after the division of subcontinent into India and Pakistan. Moreover, without much change, the laws relating to civil, criminal or contract in Pakistan are the same as under British reign enacted in the form of statutes commonly known as the Civil Code of Procedure (CPC) 1908, Criminal Code of Procedure (CrPC) 1898, or Indian Contract Act 1872.

\section{Historical background}

In 1947, the British divided the subcontinent into two independent countries on the whims and wishes of its people, namely India and Pakistan. This partition was regulated through the Indian Independence Act of 1947 resulting in the culmination or end of the British rule in the subcontinent. However, before that the subcontinent (formerly known as India) had to go through a long struggle for independence from their British colonizers. It is said that the British colonized India in 1876, yet the traces of their colonization dates back to 1757 when the British navy and traders landed in India for the first time. It was during 1760s when the British overtook India from the rule of Mughal Emperors, due to several internal and external factors. The foremost driving factors leading to British colonization included trade and military control over the subcontinent. The British employed their military for the purposes of territorial acquisition in subcontinent. In 1757, the British colonized the subcontinent through their military expedition in the Battle of Plassey, earning for themselves the privilege of ruling India for the next two hundred years.

The British Raj was based on direct administration of the two-thirds of the subcontinent in order to meet their political and economic goals. After the battles of Plassey and Buxar, the British took over the full control of Bengal by collecting revenues so as to establish the British domination over the subcontinent. Adding fuel to fire, the 1857 mutiny gave the British a perfect opportunity to establish the Crown rule through direct administration in the entire subcontinent. At first, the British allowed the native rulers or princes to administer the local populace of their states with a controlled regulation. That is, the British maintained its right to interfere in the internal affairs of such states where such states were unfaithful to the crown. After independence, these native states joined either India or Pakistan based on the treaties of accession in 1948, with no change in their legal, 
administrative, or political systems. Nevertheless, the issue of accession of Kashmir is still in the process as is evident through the history. ${ }^{1}$

Once the British maintained their control over the subcontinent, they began to work on the regulation of laws in the region. The laws were codified and enforced in India in order to ensure peace, certainty, and uniformity. Although the basic aim of these laws was to keep law and order situation, however, they were sometimes used as tool against the native population to prevent any uprisings against British rule. The British eliminated the courts and feudal rule of the Mughals and established a new kind of bureaucracy where the new aristocrats were to follow the footsteps of the British themselves. They also introduced their own language, i.e. English, along with its culture, literature and philosophy to establish their roots in the region as well as giving rise to an elite class of native Indians, who were English by cultural.

Moreover, it was one of the strategies of the British to employ the 'divide and rule' policy to instigate Hindus against Muslims and vice-versa. Through this policy, religion was used to draw a wedge between the Indians causing massive deaths and displacements along with declining pivotal economic assets. The British knew the fact that India was a region of socio-cultural diversity and in order to exploit the potential resources of this region, it was necessary to provoke and augment the Muslims against Hindus, one caste/class against the other, and the masses against the native princes. $^{2}$

\section{Impact of foreign law on the legal development of Pakistan under British colonial rule}

In 1858 the British introduced the British India Act in response to the failed 1857 rebellion, in order to transfer the power to rule the subcontinent from the East India Company (EIC) to the British crown directly. In addition, the British established a post for a Secretary of State for India, who would be counseled by a 15-member council of the British. It was the first of many steps that the British initiated to finally accomplish their Raj over the subcontinent.

Initially, the English law introduced by the British was enforced only upon the Europeans living in the sub-continent, and the Indians were regulated in their affairs of marriage, inheritance, and other matters by Islamic laws for Muslims and Hindu laws for Hindus till 1773. It is till to date not confirm that such division of laws based on religion was introduced on the premises of the divide and rule policy, yet it bore long lasting effect which led to the division of subcontinent into two While it is not clear whether this bifurcation of the law was proposed to introduce the policy of states based on religion.

In the early one-fifty years of the British rule, the British acquiesced with the applicability of native and domestic laws in matters of disputes, applying the principles of Islamic law for Muslims and Hindu law for Hindus. The reason behind this acquiescence was the codified religious laws and decisions in the subcontinent like the Fatawa-e-Alamigiri (The Edicts of Emperor Alamgir), which were already relied upon by the judges. In addition, during this time all kinds of religious texts or

${ }^{1}$ RAHMAN - ALI - KHAN, The British Art of Colonialism in India: Subjugation and Division 1-2.

2 RAHMAN - ALI - KHAN, The British Art of Colonialism in India: Subjugation and Division 4. 
laws were romanticized by the local populace, which led to convenience for the British Raj. For the purposes of achieving the British aims and targets, some of the significant religious texts were translated into English, including the Fatawa ${ }^{3}$ and Hedaya ${ }^{4}$ for Muslims, and the Dharma Shastra ${ }^{5}$ for Hindus by various English writers.

Nonetheless, this romanticism of the religious laws was quite short-lived. The British gradually became disappointed with their repeated attempts to categorize and unify various religious identities within both Islam and Hinduism. For instance, Islam is comprised of two major sects, namely Sunnis and Shia's. This broad division again comprises of further division, for example, the Sunni sect has four different schools of thought, which can be classified into further sub-groups. Therefore, it became difficult for the British to reconcile and unify all the diversity of opinions into one lump-sum code leading towards a failed legal system.

Besides, this change of attitude in the British from these religious laws can also be viewed from another less judgmental approach. The frustration of British from the religious laws and the introduction of their English common law may have arisen in an attempt to legalize their rule by being more accountable to their colonized people. Say for example, the law introduced by the British would turn them into the prisoners of their own rhetoric, that is they would have to be bound by their own laws no matter what, giving their colonizers a satisfactory feeling. However, the opponents to this point of view suggest that for the British, subcontinent was just like a laboratory where they could experiment their legal laws before implementing them in their own country. ${ }^{6}$

Many scholars have acknowledged and emphasized upon the fact that the existence or nonexistence of vibrant, persistent and durable legal institutions in any country depends upon the origin of that country's legal system. It has also been argued that a common law country posits better development conditions in contrast to a civil law country ${ }^{7}$ due to the underlying economic freedom, ${ }^{8}$ judicial independence, ${ }^{9}$ limited government, ${ }^{10}$ and efficient law-making. ${ }^{11}$ Evidence is adduced suggesting that the states formerly subject to British colonial control have experienced superior economic performance compared to states that were colonized by other European powers, at least within the financial realm. ${ }^{12}$ With regard to the impact of rule of law outcomes in both common and civil law countries, the scholars have favored the common law system based on its flexible and

\footnotetext{
3 A fatwa is an Arabic word which means a legal pronouncement in Islam made to clarify a question where Islamic jurisprudence is unclear. It is pronounced by an Islamic scholar on the request of a judge or any other qualified person.

${ }^{4}$ Hedaya is an Arabic word meaning 'guidance'. According to Islamic belief, guidance has been provided by Allah to humans primarily in the form of the Qur'an. It basically means the translation of the Holy Quran.

${ }^{5}$ Dharma-shastra is an ancient Indian body of jurisprudence that is the subject to legislative modification, of the family law of Hindus.

${ }^{6}$ RAHMAN - ALI - KHAN, The British Art of Colonialism in India: Subjugation and Division 12-14.

${ }^{7}$ See Botero - DjANKOV - PORTA - SilaneS - SHLEIFER, The Regulation of Labor.

${ }^{8}$ LEVINE et al., Financial Intermediation and Growth.

${ }_{9}^{9}$ Merryman, Codes and Codification 26-33.

10 See MAHOnEY, The Common Law and Economic Growth.

${ }^{11}$ Rubin, Growing a Legal System in the Post-Communist Economies 10.

12 See RAJAN - ZingALES, The Great Reversals.
} 
adaptable nature, that is to say the common law is based on the body of case laws which could easily develop in any country in such a way that corresponds to the needs of the society. ${ }^{13}$

In support of the legal development of the British colonies, especially Pakistan, there exist four eminent theories that suggest the impact of common law on their legal and economic spheres. Firstly, there is the legal origins thesis ${ }^{14}$ theory which suggests that it is that kind of legal system adopted by a country that determines its subsequent legal, institutional and economic development. The British imposed common law system in their colonies including Pakistan and this system led such colonies towards superior developments as mentioned earlier. Secondly, there comes the 'endowment theories ${ }^{15}$ which emphasize upon the influence or impact of the initial and existing conditions on the performance of the subsequent development in the legal and economic arenas. They stress that development of a country depends potentially upon the initial conditions and the legal institutions developed in cognizance with them. Thirdly, 'the transplantation effect' theory helps to address the failures of the two prior by explaining the correlation between the legal origins and legality - defined as "the extensive and effectiveness of legal institutions". 16 This theory proposes that by transplantation i.e. the process of adaptation and the harmony between the new and old laws bears potential significance than the substance of law itself. ${ }^{17}$ According to this theory, if a law adequately addresses a perceived societal need or controversy, the citizens would have an incentive to use the law and to demand institutions that work to enforce and develop the law, ${ }^{18}$ and if the system allowed the legal intermediaries responsible for its implementation and administration to the changing needs of the public; popular support would remain high, strengthening legal institutions as a whole for the long-term. Lastly, the 'theories of legal change' propose that change in legal systems is explained in terms of overall economic or cultural evolution or in terms of the satisfaction of particular social needs, but these theories do not say much about the precise content of legal change. Even Donald Horowitz ${ }^{19}$ argues that no adequate general understanding of legal change currently exists.

The British colonization of foreign lands and the subcontinent itself, led to fundamental changes in the colonizers, institutional structures, historical trajectory of the colonized areas, and subsequent rule of law performance of these former colonies. Although the initial conditions like the cultural, physical, economic, and institutional endowments of the British colonies had significant impact upon the former models and choices of administration, yet it were the subsequent and intentional institutional arrangements of the British that bore ultimate impact upon their modern day rule of law trajectory. Thus, it can be concluded that it is the colonial experience instead of the initial conditions that prove to be decisive in the development index of a colony. There exist two utmost features of colonial administration and legal transplantation which suggest the existence of long run, stabilized and vibrant colonized countries (or lack thereof): I. The degree of representation in

\footnotetext{
13 RAHMAN - ALI - KHAN, The British Art of Colonialism in India: Subjugation and Division 1-2.

14 BECKS - LEVINE, Legal Institutions and Financial Development.

${ }^{15}$ ENGERMAN - SOKOLOFF, Factor Endowments, Inequality 56-64.

${ }^{16}$ BERKOWITZ et al., The Transplant Effect 167.

${ }^{17}$ MonTesquieU, The Spirit of Laws 1748.

${ }^{18}$ BERKOWITZ et al., The Transplant Effect 167.

${ }^{19}$ See Horowitz, The Quran and the Common law.
} 
legislative bodies afforded to the native population; and II. The degree to which native and British common law courts and animating values were integrated, fostering the development of localized common law jurisprudence. These two features highlight the significance of the intersection between imported / formal policies and native institutions / norms in reinforcing or undermining one another and ultimately in supporting or inhibiting the development and perpetuation of strong legal institutions. ${ }^{20}$

Perhaps attributable to its unique importance to the British Empire as well as the lengthy duration of British engagement in the subcontinent, ${ }^{21}$ India's colonial history exposes the extensive diversity of administrative approaches employed by the British officials in governing this vast territory. India was thus administered as a direct/indirect rule hybrid, with varying degrees of involvement by colonial officials. While colonial officials were slow to engage the native populations in the law-making process in British India, their cautious approach to the transplantation of the legal system and rules reflected their acknowledgement of the pre-existing Hindu and Muslim codes of conduct. Before replacing the justice system, the British introduced the fundamental values of consistency and formality in the pre-existing courts in India. Although it is a well-known fact that the modern-day legal system of both India and Pakistan is entirely English, yet no single Act or Statue bears evidence to the implementation of common law system. The British approach for introducing changes in piecemeal in the Indian legal system proved to be effective in two ways; 1) availing them the chance of testing their policies on the native population, and 2) affording the native population the necessary time to adjust to new laws. Eventually, this strategy of the British gave them full control over the formulation of an effective and functional legal system in India during their reign. Through the gradual adaptation of the legal system, British were capable of establishing a proper court hierarchy along with a body of laws which was accepted by the local people. The two important factors (administrative flexibility and responsiveness) ensured strong and stable institutions in the subcontinent even in the face of extreme challenges.

It can be seen that the legislative history in the subcontinent reflects a gradual yet an inevitable progression for a representative government. Initially the authority for legislation was vested in the EIC's Board of Directors based in England. However, by 1726, this situation was altered and British established their own legislative bodies in all the three presidency towns of Madras, Bombay and Bengal to be administered by Crown officials. Unfortunately, these bodies introduced such laws that lacked a systematic organization accompanied with poor publication. The Charter Act of 1833 came to the rescue by strengthening the movement towards legal standardization and centralizing the legislative process in the Governor-General and his Legislative Council. It also directed for the codification of law in the subcontinent, by combining and collecting all the legal sources including regional regulations, acts of parliament, Hindu and Muslim personal law, Islamic criminal law, and the widely construed Roman principles of justice, equity and good

\footnotetext{
20 DANIELS - TreBILCOCK - CARSON, The Legacy of Empire: The Common Law Inheritance and Commitments to Legality in Former British Colonies 11-78.

${ }^{21}$ RAJAN, The Impact of British Rule in India 89.
} 
conscience, ${ }^{22}$ in order to form a one uniform piece of great legal work contained in one whole. The Governor-General possessed veto power on all Council acts and was authorized to exercise his exclusive power over matters related to taxation, military, and foreign relations.

Besides possessing wide ranging powers wielded by the Council, the British still felt the need to provide a certain degree of representation to the local population in the legislative process of their country. This recognition by the Crown officials was as a result of the aftermath of the Indian Rebellion of 1857. The British enacted the Indian Councils Act in 1861 that aimed at transforming the Legislative Council from a body of executives and bureaucrats into a representative legislature. Over the course of next fifty years, it was seen that the local population came to bear increased opportunities for the representation in the Council, although inconsistent in nature. ${ }^{23}$ This act of involving the native population into the legislative process proved to be effective for two specific reasons; 1) the training of the post-independence leaders, and 2) to provide legitimacy to the established government institutions. The organization of political parties like Indian National Congress and Muslim League gave way to growing political awareness among the Indians and heightened opportunities for them to participate in their law-making process and governance. By the time of independence in 1947, Indians had nearly ninety years of experience with some degree of representative legislation and responsive government, a background crucial in promoting strong respect for the rule of law.

Speaking of the jurisdictional institutions set-up by the British in their colonies, it can be seen that although such arrangements varied throughout their colonial territories, yet they provide a certain level of integration between the both - the British and native institutions. There existed two different kinds of jurisdictional arrangements made by the British. One was the parallel jurisdictional model where both the systems (the British courts and local institutions) worked independent of each other by employing particular regulations based on specific types of cases or parties to be dealt with under each system. The other was the integrated jurisdictional model where both the systems (the British and native institutions) worked in an integrated manner by allowing a more porous mode of exchanging and adapting the norms and values of one-another. ${ }^{24}$

In case of the subcontinent, the British laid down the jurisdictional arrangements based on the Administrative and Judicial Plan of 1772. Under this plan, the then Governor General Warren Hastings established a series of civil courts or the Diwani Adalats, in the less developed areas under the supervision of British officials. ${ }^{25}$ Thus, the British officials were put in charge with administering the Hindu and Muslim personal law, British common law, regional regulations, acts of parliaments, and the Roman principles of the advancement of justice, equity and good conscience ${ }^{26}$ - as well as Muslim criminal law for certain cases - for a huge local populace. ${ }^{27}$ While aided by native advisors trained in

\footnotetext{
${ }^{22}$ KOLSKY, Codification and the Rule of Colonial Difference: Criminal Procedure in British India 63.

${ }^{23}$ The Indian Councils Act 1909 (9 Edw. 7 Ch. 4).

24 Montesquieu, The Spirit of Laws 165.

${ }^{25}$ HAMID, A Chronicle of British Indian Legal History 46.

${ }^{26}$ POLLACK, The Expansion of the Common Law 103.

${ }^{27}$ HorowiTz, The Quran and the Common law 631.
} 
their respective religious customs, ${ }^{28}$ British officers were sometimes unfamiliar with the task of drafting a unanimous and coherent and consistent body of law from the overabundance of often contradictory legal authorities. In addition, by the time that India was transferred to crown colony, there existed no fewer than seven 'highest' appellate courts operating in India and in the face of this legal chaos, British officials merged the three supreme courts and four sadar adalats into three high courts in the presidency towns with the High Courts Act of 1861. The principle of stare decisis was emphasized in the new structural arrangement, fostering the generation of a more consistent body of foreign law. ${ }^{29}$ British accomplished a simple system of pleading and practice, uniform as far as possible throughout the whole jurisdiction, that was aided by the deliberate compilation and publication of the substance and process of Indian law as well as the convocation of a series of law commission which developed comprehensive criminal and procedural codes. They also made concerted efforts to engage the local populace in the adjudicating process, beginning with the Hindu and Muslim advisors that assisted British officers in Diwani adalats, vakil system, and recruitment of judges etc. The calculated attempts of the British authorities to incorporate Indian norms and personnel into the legal system fostered the development of strong judicial institutions with strong ties to the local population, well-equipped to respond effectively to shifts in citizen demands.

When Pakistan came into being in 1947, the laws in force during the British rule remained intact. There never existed any intention to bring any changes to the body of laws introduced by the British in the entire legal history of Pakistan or to begin the statute work afresh. According to the vision of the founder of Pakistan Quaid-e-Azam Muhammad Ali Jinnah a system of law coherent and in accordance with the teachings of Islam shall be governed in Pakistan, which however could not become a reality by then. But in later times during the era of constitution making and the reign of General Mubammad Zia-ul-Haq, Islamic principles were introduced by way of a new law (Islamic Sharia law) and incorporated in the Pakistani law, thereby leading to the establishment of a new institution namely, the Federal Shariat Court (FSC). The FSC was authorized with the exclusive power of giving rulings on laws whether they are in accordance with the Islamic teachings or not. There exists a system of implementing local or traditional methods in some areas and tribes of Pakistan for settling the disputes among people commonly known as the 'Jirga System', a council of tribal elders. ${ }^{30}$

Furthermore, the Quaid-e-Azam also provided the nascent country with a much-needed political ideology. When he was a student of law at Lincoln's Inn in London, he became aware of the concept and implementation of British liberalism that inspired him a lot. This inspiration led to the modern-day Pakistani common law being based upon the common law of England and Wales. He became an ostensible figurehead of the politics of Pakistan which laid the foundations of Pakistan on the common law system, with an adversarial court system and follows other common law practices including the judicial precedent and the concept of stare decisis. Nevertheless, Pakistan still differs from the classic common law system in some ways. Firstly, the laws related to civil and

\footnotetext{
28 JAIN, Outlines of Indian Legal History 94.

${ }^{29}$ HAMID, A Chronicle of British Indian Legal History 601.

30 SAIGOL, Pakistan's Long March 208-210.
} 
criminal matters are codified which is believed to be the legacy and initiative of the British when they introduced the English laws in the form of Statutes in the subcontinent. ${ }^{31}$ Secondly, the judicial procedure comprising of the jury for a trial no longer exists in Pakistan due to the public distrust with its functioning. Thirdly, with regard to the constitutional law matters, Pakistan follows the United States legal system. That is to say, Pakistan's legal jurisprudence has adopted the concept of US-based Federal Structure. Last but not the least, Pakistani law has also been influenced by the Islamic law and traditional jirga-based law leaving an impact on the country's judicial development.

\section{Codified law in Pakistan besides Europe}

The Europe is a best-known example of having laws in codified forms like the Statutes. For every field of civil or criminal law, there exist extensive laws in the form of statutes or codes e.g. the contract law, intellectual property law, code of criminal procedure, code of civil procedure and so on. It seems indisputable that the civil law offers itself more easily and readily to the process of codification than does the common law. This fact can be understood in a more vivid way by looking upon the historical background or elements that gave way to the formation of these two unique and independent systems of laws.

The common law system is based on the concept of stare decisis, that is to mean it proceeds from case to case and is basically judge-made law. The lawyers in any common law system recognize the fact that common law is not based on certain specific abstract principles without bearing any practical value in real situations or cases. This system is regarded as conservative, based as it is on tradition. It is contrary to sudden and frequent changes, therefore tends to be indifferent to deductive reasoning. There exist no consistent set of rules to be applied in any particular situation, which means inconsistent rules find their application in similar kinds of situations based on their distinctions either from one or from another legal relation or branch of law such as contract or property law, which classify such cases. Based on this situation, the fact is a common law lawyer would not be upset by two differing rulings in a similar situation because the history accounts for such a situation and several cases provide insight to the fact.

Whereas the civil law system is more of a deductive type instead of being inductive as the common law system. The civil law system is permeated into one whole body of law provided with basic general principles that need to be applied in several situations, with regard to all fields of law. From this whole, details of rules to be applied in particular situations are drawn and deducted. According to the civil lawyers, the legal system is one whole, coherent and logical body of laws and they consider the various branches of law to be interrelated leading to the fact that the principles of one branch cannot work independent of another for a proper application. They believe that the law should be capable of fast alteration by the process of legislation acting prospectively to the changes in society, thus rendering all such laws inexistent which no longer conform to the societal needs.

\footnotetext{
${ }^{31}$ Imperial Gazetteer of India, The Indian Empire 59-60.
} 
The process of development of these legal systems naturally left an impact and influence upon the development of various branches of law, formation of law and the legal profession in both the common law and civil law nations. The center of legal thought in the civil law nations revolves around the universities where the professors of law are held in high esteem for their logical methods of methods of understanding, interpreting, and formulating the law. In Europe, it is the law professor whose authority is considered to be akin to a priest of a church, who is acknowledged for his wit and superiority by the courts as well. Instances of several cases been decided by such law professors have been witnessed due to the of 'transmission of the docket,' according to which courts at one time sent the records of difficult cases to law professors and asked them for opinions. ${ }^{132}$

Furthermore, as mentioned above, the British made efforts to codify the laws in India trying to formulate an Anglo-Indian law that would aim towards having a unified and predictable modern legal system, meant to regulate economic, political, and social relations between individuals and groups. By so doing, the British tried to justify their claim to bring and ensure. Whereas in reality, such claims were made to in an attempt to distinguish the Europeans from Indians. However, till to date it can be witnessed that the legal legacy of the British is still in force in India, Pakistan, and Bangladesh. The Indian Contract Act, Police Act, the Evidence Act, the Penal Code, the Jail Code, and many other laws have been inherited from the British times. While the Indian sub-continent has been independent for over seventy years, the continued existence of these laws reflects the viability and utility of these laws being employed by the British rulers to administer their colonizers. ${ }^{33}$

Specifically speaking, the Indian Contract Act of 1872 is still in force in Pakistan. This Act is a fundamental law relating to contracts and a key Act in regulating the contract law. The basis of the Act is derived from the English common and it is applied to all parts of the country, until specified otherwise. It is through this Act that the conditions and circumstances are taken to be legally binding upon the parties entering into contracts or promises. Under Section 2(h), the Indian Contract Act defines a contract as an agreement which is enforceable by law. ${ }^{34}$ When the Act was originally enacted, it comprised of 266 Sections, having a wide scope including; General Principles of Law of Contract - Sections 01 to 75, Contract relating to Sale of Goods - Sections 76 to 123, Special Contracts- Indemnity, Guarantee, Bailment \& Pledge and Agency - Sections 124 to 238, and Contracts relating to Partnership - Sections 239 to 266. But at present, this Act can be divided into two parts, where part 1 deals with the General Principles of Law of Contract Sections 1 to 75, and part 2deals with Special kinds of Contracts such as Contract of Indemnity and Guarantee, Contract of Bailment and Pledge and Contract of Agency.

The Act came into force during the times of industrial revolution, when the British courts became aware of the significance of the idea of 'freedom of contract'. This awareness was of essence for the people of India as it lifted the mercantile and feudal imposed restrictions on the workers as well as the businesses, thus making a move of people from 'status to contract'. In contrast, a bias for laissez faire thought obscured the inequality of trading power in terms of employment, consumer,

\footnotetext{
32 WaGner, Codification of Law in Europe and the Codification Movement in the Middle 332-337.

${ }^{33}$ RAHMAN - ALI - KHAN, The British Art of Colonialism in India 19.

34 Section 2(h): The Indian Contract Act 1872 (Act No. 9 of 1872).
} 
and tenancy contracts. But with the concept of freedom of contract by way of a generalized contract law, everybody shared the same degree of free will in every kind of agreement they entered. The English Courts also became very cautious of any interference in any kind of agreement or contract. For instance, in the Printing and Numerical Registering Co $\mathrm{v}$ Sampson, Sir George Jessel MR proclaimed that 'contracts when entered into freely and voluntarily shall be held sacred and shall be enforced by Courts of justice. ${ }^{35}$ With the enactment of the Judicature Act in 1875, common law was merged with the Chancery Courts, however, the principles of equity always took precedence above them. Yet the basic principles of the contract law remained intact and stable, that is a contract included an offer mirrored by an acceptance and supported by free will and consideration to be legally enforceable. These principles were later exported to the entire British Empire. In addition, the pre-requisites of fairness, obligations of good faith and disclosure were felt need less due to the fact that liabilities 'are not to be forced upon people behind their backs, ${ }^{36}$ Parliament's statutes, outside general codifications of commercial law like the Sale of Goods Act 1893, left people to the harsh freedom of contract of the market until the property qualifications for Parliament were reduced, and the electoral vote finally became democratic. ${ }^{37}$

The modern day contract law is a product of the industrial revolution and social legislation of the twentieth century. Present-day contract law respects free markets, regulate the freedom of powerful contractors, safeguard the rights of weaker parties, and affect social policy concerning matters of consumer protection, employee rights, and business ethics. As this contract law is enacted by the British, it continues to bear the traditional roots of common law legal system in Pakistan. By common law legal system, it is hereby referred to such parts of the law that have their basis on the courts decisions, as opposed to the statutes or acts enacted by the legislature of a country. In Pakistan, the Indian Contract Act, 1872 deals with the matters of contracts. This act seeks to codify the common law by taking all the rules and principles already developed by judges and arranging them together in the form of an act, to clarify the law or to make it more accessible. This attempt or the like thereof also help in initiating a reform or modernization of the existing common law rules or in formulating new rules to deal with problems yet not decided by the courts. Besides providing a considerable attention to the contracts through the process of legislation, the area of contract law is yet considered part of the common law as it is still dominated by the judge-made rules and customs. ${ }^{38}$ The rules of common law are made keeping view an actual case that comes in the realm of the courts, where the judge(s) decide such case by consulting enormous law reports, digests and citations to discover a suitable precedent that covers the legal case in hand. Once he finds out the right solution to the problem and concludes after rigorous analysis that his/her judgment is one of its own kinds, then such judgment shall become a new law itself. The emphasis on the judge-made law had a strong bearing on the common law system from the doctrine of separation of powers, as

\footnotetext{
35 See Printing and Numerical Registering Co v Sampson 1875.

36 See Falcke v Scottish Imperial Insurance Co.

37 The Representation of the People Act 1883 (1983 c. 2).

38 See GODDARD - FELLNER - ORMAND, Basic Principles of Contract Drafting.
} 
England had no concept separation among the three basic branches of the state: the legislature, executive, and judiciary. ${ }^{39}$

The Indian contract law is in regulation not only in Pakistan, but also in India, Bangladesh and Burma. The act was passed by the British keeping in view the sentiments of the local populace of their colonies that was basically a piece of ordinary legislation, deliberately planned and formally enacted in the region. Besides the Indian sentiments, the Act was by and large based on the English common law principles. Prior to this act, matters of contracts were decided by the Indian courts in accordance with the law and customs of Hindus/Muslims, depending upon the religion of the parties. But with the enactment of this act, the religious afflictions were all demolished and a new, uniform set of rules based on common law was applied and extended to the whole of India. ${ }^{40}$

Although the act was based on the principles of English common law, yet there are some differences between the principles enacted and those found in the common law. A few of them are because while provisions of the act are unchanged, the principles of common law have experienced modification over the years. Some other differences may also be due to the change in the social environments of both India and England. Therefore, a few differences between the two have been cited for a clearer understanding. Firstly, in case of the Act in India, consideration is essential to prove the existence of legal intention to bind parties to the contract and considered as a nonnegotiable element. While in the case of common law in England, the situation is an inverse reality, that is to say that consideration is only regarded evidentiary in order to create a legal relationship between the parties. Secondly, as mentioned above, although consideration is taken to be a significant element in any legal engagement under the act, yet there exist certain circumstances where consideration may be waived such as contract made out of love and affection. ${ }^{41}$ Whereas, this is not the case with common law as it regards consideration as only having an evidentiary value. Thirdly, according to the act, every person to whom the promise is made may either dispense with or remit, wholly or in part, the performance of the promise made to him. ${ }^{42}$ Whereas in common law, any rescission or alteration of a contract has to be affected by means of a new agreement and that should in general satisfy all the requirements of a contract. These and other variations from the common law seem to have been induced by the desire to amend certain rules of the common law or by the feeling that circumstances in Pakistan or India necessitated such departure and proved to be relevant in her context.

\section{Conclusion}

Keeping in view the fact that the European civil law stands as an epitome of bearing codified laws in the continent, yet there are other countries in the world that follow their lead. Pakistan is a living example of such a phenomenon. Although Pakistan has been colonized by the British for a long

\footnotetext{
39 WAGNER, Codification of Law in Europe and the Codification Movement in the Middle 337-339.

${ }^{40}$ MinAtTur, The Indian Contract Act: Its Wanderlust and Warmer Climes 107-108.

${ }^{41}$ Section 25(1) of the Indian Contract Act 1872.

42 Section 63 of the Indian Contract Act 1872.
} 
period of time, yet the British brought a change in their policy of non-codified laws to a body of codified laws in the subcontinent region. These codified laws can be found in the fields of civil as well as criminal laws, based largely on the principles of common law and equity. In this paper, a comprehensive analysis of the history of Pakistan's codified law and its impact on the legal development of the country is provided. For the purposes of a vivid understanding of the phenomenon of codified private law outside the realm of Europe, an example of the Indian Contract law of 1872 in force in Pakistan has been cited in detail, encompassing the history, traditional roots and departures from the traditional roots of the act.

\section{Bibliography and sources}

BAKER, J. Hamilton - Francis, Stroud - Milsom, Charles: Sources of English Legal History: Private Law to 1750. Butterworths 1986

BECKS, Thorstan - LEVINE, Ross: Legal Institutions and Financial Development. In: MENARD, Claude - SHIRLEY, Mary: Handbook of New Institutional Economics. SpringerLink 2005

BERKOwITZ, Daniel et al.: The Transplant Effect. American Journal of Comparative Law, Volume 51, 163/2003

Botero, Juan - DjANKov, Simeon - LA PORTA, Rafael - LOPEZ-DE-SILANES - LEVINE, Florencio Ross et al.:

Financial Intermediation and Growth: Causality and Causes. Journal of Monetary Economics, Volume 46, $31 / 2000$

Burrows, Andrew: English Private Law - Oxford principles of English law. Oxford 2013

Chandrika, M.P. A Comparative Analysis of U.K. and Indian Provision relating to Intention under Law of Contract. International Journal of Law and Legal Jurisprudence Studies, Volume 3, 4/2016

Coquillette, Daniel R.: Comparative Studies in Continental and Anglo-American Legal History. Civilian Writers of Doctors' Commons, London: Three Centuries of Juristic Innovation in Comparative, Commercial and International Law. Duncker \& Humblot 1988

DAniels, Ronald J. - Trebilcock, Michael - CARSOn, J. Lindsey D.: The Legacy of Empire: The Common Law Inheritance and Commitments to Legality in Former British Colonies. The American Journal of Comparative Law, Volume 59, 1/2011

Engerman, Stanley - SOKOLOFF, Kenneth L.: Factor Endowments, Inequality, and Paths of Development among New World Economies. JSTOR, Volume 3, 41/2002

Goddard, Chris - Fellner, Amy - Ormand Rue-Ann: Basic Principles of Contract Drafting Course Materials. https:/ / docplayer.net/21484350-Basic-principles-of contract-drafting-course-materials-chris-goddard-withamy-fellner-and-rue-ann-ermand.html (19. 10. 2019)

HAMID, Abdul: A Chronicle of British Indian Legal History. India 1991

Horowitz, Donald L. The Quran and the Common law: Islamic Law Reform and the Theory of Legal Change. American Journal of Comparative Law, Volume 42, 1994, 233-543

Imperial Gazetteer of India: The Indian Empire. Historical, Volume 2, 573/1908

JAIN, M.P.: Outlines of Indian Legal History. Bombay 1996

JUDD, Denis: The Lion and the Tiger: The Rise and Fall of the British Raj, 1600- 1947. Oxford 2005

KOLSKY, Elizabeth: Codification and the Rule of Colonial Difference: Criminal Procedure in British India. Law \& History Review, Volume 23, 631/2005

LAU, Martin: Introduction to the Pakistani Legal System, with Special Reference to the Law of Contract. Yearbook of Islamic and Middle Eastern Law, Volume 1, 1994

LYON, Ann: Constitutional History of the UK. Routledge 2016

Mahoney, Paul: The Common Law and Economic Growth: Hayek Might Be Right. Journal of Legal Studies, Volume 
$30,503 / 2001$

Merryman, J. Henry: Codes and Codification. In: Beth Roemer (2nd ed.): The Civil Law Tradition: An Introduction to The Legal Systems of Western Europe and Latin America. Stanford 1985

MinatTuR, Joseph: The Indian Contract Act: Its Wanderlust and Warmer Climes. Journal of the Indian Law Institute 1972

POLLACK, Frederick Bart: The Expansion of the Common Law. London 1904

Rahman, Aziz - Ali, Mohsin - KHAn, Saad: The British Art of Colonialism in India: Subjugation and Division. Peace and Conflict Studies, Volume 25, 2018/1 Article 5

RAJAN, M.S.: The Impact of British Rule in India. Journal of Contemporary History, Volume 4, 89/1969

Rajan, Raghuram - Zingales, G. Luigi: The Great Reversals: The Politics of Financial Development in the Twentieth Century. Journal of Financial Economics, Volume 69, 5/2003

RIVER, Charles: The British raj: the history and Legacy of Great Britain's Imperialism in India and the Indian Subcontinent. Createspace Independent Publishing Platform 2017

RUBIN, Paul H.: Growing a Legal System in the Post-Communist Economies. Cornell International Law Journal, Volume 27, 1/1994

SAIGOL, Rubina: Pakistan's Long March. Development and Cooperation, Volume 36, 5/2009

SHLEIFER, Andrei: The Regulation of Labor. Quarterly Journal of Economics, Volume 119, 1339/2004

The Indian Councils Act 1909: 9 Edw. 7 Ch. 4 https://en.wikipedia.org/wiki/Government_of_India_Act_1919.(31. 12. 2019)

The Indian Contract Act (Act No. 9 of 1872) http://www.vakilno1.com/bareacts/indiancontractact/indiancontractact.html (31. 12. 2019)

The Representation of the People Act 1883 https://en.wikipedia.org/wiki/Representation_of_the_People_Act_1983 (31.12. 2019)

Treitel, Guenter: Some Comparative Notes on English and American Contract Law. SMU Law Review, Volume 55, $1 / 2002$

WaGNER, Wencelas J.: Codification of Law in Europe and the Codification Movement in the Middle of the Nineteenth Century in the United States. Paper 2324, Indiana 1953

WEISs, Gunther A.: The Enchantment of Codification in the Common Law World. Yale Journal of International Law, Volume 25, 2/2000 435-532. 